\title{
EU Joint Action on Vaccination ja muut ajankohtaiset toimet rokotuskattavuuden vahvistamiseksi EU:ssa
}

Mennyt talvi ja kevät on jälleen osoittanut, että tartuntataudit eivät kunnioita maiden rajoja ja että virus, jota vastaan ei ole aiempaa suojaa eikä rokotetta, voi saada myös rikkaat maat polvilleen. Mutta jo ennen SARS-CoV-2-viruksen aiheuttamaa koronapandemiaa EU:n jäsenmaat ovat halunneet lisätä maiden välistä yhteistyötä tartuntatautien torjunnan ja rokottamisen saralla.

Monissa jäsenmaissa rokottamiseen on viime vuosina liittynyt haasteita rokotteiden saatavuuden ja rokotuskattavuuden osalta, minkä seurauksena esimerkiksi tuhkarokkoon on EU-maissa sairastunut ja kuollut sekä lapsia että aikuisia, vaikka tauti olisi rokottamisella helposti ja hyvin estettävissä. Vähentynyt ymmärrys rokotteiden kansanterveydellisistä hyödyistä, epäluottamus tieteelliseen tutkimukseen ja pelko mahdollisista haittavaikutuksista on myös johtanut rokotusvastaisuuden lisääntymiseen. Vaikka kansallinen rokotusohjelma ja rokottaminen kuuluvat EU:ssa jäsenmaiden toimivallan piiriin, Euroopan unioni on ottanut isoja askelia jäsenmaiden tukemisessa.

EU-tasolla merkittävin askel otettiin, kun Euroopan neuvosto hyväksyi joulukuussa 2018 rokotussuositukset, joiden tavoitteena on tukea jäsenmaita, vähentää rokotusvastaisuutta, parantaa rokotuskattavuutta ja rokotteiden saatavuutta, lisätä hankintoihin liittyvää yhteistyötä, tukea tutkimus- ja kehitystyötä, sekä vahvistaa unionin näkyvyyttä maailmanlaajuisessa terveysyhteistyössä (Euroopan unionin virallinen lehti 2018).

Suositusta varten on suunniteltu ja on jo käynnissä iso määrä konkreettisia toimenpiteitä, joiden aikatauluja ja tavoitteita on eritelty niin sanotussa "rokotustiekartassa" (EU Roadmap on Vaccination 2018). Tiekartassa kuvattuja toimenpiteitä ovat muun muassa rokotteiden saatavuuden turvaaminen, kansallisten rokotusrekiste- reiden yhdenmukaistaminen, tutkimustoiminnan tukeminen ja EU:n yhteinen, sähköisesti jaettava rokotuskortti. Näitä tavoitteita varten komissio on käynnistänyt sekä rahoitushakuja että eri toimijoiden yhteistyötä lisääviä aloitteita.

Vaikka Suomen tilanne on moneen muuhun EU-maahan verrattuna tällä hetkellä hyvä niin rokotuskattavuuden kuin -luottamuksenkin suhteen, emme kuitenkaan ole vastustuskykyisiä kansainvälisille vaikutuksille liittyivät ne sitten rokotusvastaisuuteen tai muihin rokotustoiminnan haasteisiin (Sivelä et al. 2018, Tiedebarometri 2019, Lääkebarometri 2019).

\section{YHTEISTYÖN LISÄÄMINEN}

Perinteisesti maiden välistä rokotusyhteistyötä on tehty Euroopan tartuntatautivirasto ECDC:n ja Maailman terveysjärjestö WHO:n koordinoimana. Kansallisten rokotusasiantuntijatyöryhmien verkosto perustettiin vuosi sitten ajatuksella, että laajojen näyttökatsausten tekeminen ja rokotussuositusten laatiminen olisi järkevämpää yhteistyössä kuin kunkin maan omana ponnistuksena. EU-maiden yhteydenpitoa on myös lisätty WHO:n Strategic Advisory Group of Experts on Immunization SAGE:en sekä WHO EURO:n the European Technical Advisory Group of Experts on Immunization ETAGE:en.

Euroopan komissio on lisännyt omaa rooliaan tuhkarokkoepidemioiden myötä ja pandemioihin varustautuessa vuoden 2009 sikainfluenssapandemiasta opittua hyödyntäen. Erilaisia aloitteita on syntynyt tiheään. Hyvä esimerkki on Coalition for Vaccination, joka on koonnut yhteen erilaisia rokottamisen puolesta työtä tekeviä kansalais- ja ammattijärjestöjä ajatuksella, että rokotusluottamus syntyy nimenomaan dialogissa asiantuntijoiden ja kansalaisten välillä. 


\section{ROKOTTEIDEN SAATAVUUTEEN LIITTYVÄ YHTEISTYÖ}

Rokottamisen haasteisiin liittyen keskustelun keskiössä on usein rokotusvastaisuus, ja harvemmin puhutaan - ainakaan julkisessa keskustelussa - rokotetuotannon ja rokotteiden saatavuuteen liittyvistä ongelmista. Lääketeollisuuden fuusioista seurannut rajallinen rokotetuotantokapasiteetti on johtanut rokotepulaan, mikä on vaikeuttanut myös Suomen rokotusohjelman toteutusta.

EU-komissio on käynnistänyt selvityksen lääkkeiden ja rokotteiden saatavuusongelmien syistä ja keinoista puuttua näihin. Rokotteiden saatavuutta normaalioloissa ja kriisitilanteissa halutaan parantaa ja pyritään vähentämään rokotepulan riskiä. Komissio ehdottaa muun muassa keskustelua lääketeollisuuden kanssa eurooppalaisen rokoteteollisuuden toimintamahdollisuuksien edistämiseksi, rokotetuotannon ja toimitusvarmuuden lisäämiseksi, sekä useampien rokotevalmistajien saamiseksi mukaan tarjouskilpailuihin ja rokotepuskurivarastojen luomista epidemioita varten.

Rokotehankintoihin halutaan lisää yhteistyötä esimerkiksi rokotteiden tarpeen, määrän ja varastotilanteen arvioimiseksi, mutta myös hankittavien valmisteiden arvioinnin ja laatuvaatimusten osalta. Tähän tarvitaan jäsenmaiden vapaaehtoista tietojenvaihtoa esimerkiksi rokotteiden saatavuudesta ja puutteista. Yhteisen virtuaalivaraston perustamista on myös ehdotettu.

Koronapandemia tekee rokotteiden saatavuuteen ja tuotantoon liittyvät haasteet entistä ajankohtaisemmiksi niin kansainvälisesti kuin Suomessa. Toimintamalleja rokotteiden vaihdon mahdollistamiseksi jäsenmaiden kesken esimerkiksi kriisi- tai epidemiatilanteessa on toivottu kehitettävän, ja Euroopan unioniin on luotu yhteishankintamekanismi, johon kaikki maat Suomi mukaan lukien ovat liittyneet. Tätä kautta on hankittu sekä lääkkeitä että lääkinnällisiä laitteita ja paraikaa, elokuussa 2020, neuvotellaan yhteisten COVID-19 rokotteiden hankinnasta huolimatta siitä, että yhdestäkään rokoteaihiosta ei ole vielä tehotutkimustietoja saatavilla.

\section{TUTKIMUKSEN TUKEMINEN}

Rokotteisiin ja rokotustoimintaan liittyvää tutkimusta edistetään EU:n III terveysalan toimintaohjelman sekä julkis-yksityisen rahoitusinstrumentin Innovative Medicines Initiativen kautta. Tavoitteiden keskiössä ovat erityisesti rokotuskattavuu- den ja -luottamuksen vahvistamiseen liittyvän kansanterveystyön ja tutkimuksen tukeminen.

Rokotusluottamukseen ja -kattavuuteen liittyviin toimenpiteisiin kuuluu muun muassa vuonna 2019 julkaistu H2020-erityishaku, jonka tavoitteena on vahvistaa tutkimusta rokotusluottamuksesta sekä edistää rokotuskattavuuden tähtäämiseksi tarkoitettujen toimenpiteiden kehittämistä. Haun tulokset julkistetaan syksyn 2020 aikana. EU-komissio teettää myös säännöllisesti State of Vaccine Confidence in the EU -kyselytutkimuksen, jonka tarkoitus on seurata rokotusasenteita ja niissä tapahtuvia muutoksia Euroopassa.

Koronarokotetutkimus on innostanut tiedeyhteisöä ja asiantuntijavirastoja. Tutkimusohjelmien koordinaatiossa ja myyntilupaprosessin nopeuttamisessa tehdään paljon yhteistyötä, jotta koronarokote saataisiin käyttöön mahdollisimman pian. Tällä hetkellä tunnetaan ainakin 231 rokoteaihiota, joista 34 on kliinisissä kokeissa, joista ensimmäisiä laajempia tutkimustuloksia on odotettavissa ehkä jo tänä syksynä.

\section{EU JOINT ACTION ON VACCINATION}

Pirstaloitumisen ehkäisemiseksi EU pyrkii kokoamaan eri toimenpiteitä ja hankkeita yhteen. Elokuussa 2018 alkanut kolmivuotinen EU Joint Action on Vaccination (EU-JAV) -yhteishanke vie eteenpäin useita Euroopan unionin rokotussuosituksessa asetettuja tavoitteita. Hankkeen pääasiallinen tarkoitus on luoda konkreettisia työkaluja rokotuskattavuuden vahvistamiseksi EU:n jäsenmaissa, lisätä kansanterveyslaitosten välistä yhteistyötä sekä kehittää uusia yhteistyömalleja. EU-JAV-hankkeessa on mukana yhteensä 20 maata. Hanketta koordinoi Ranskan kansallinen terveystutkimuksen laitos, Inserm. EU-JAV-hankkeen kokonaisbudjetti on 5,8 miljoonaa euroa, ja sen kustannuksista vastaavat EU-komissio ja osallistujamaat yhdessä.

Joint Action on EU-komission ja jäsenmaiden yhteinen rahoitusmekanismi, jolla pyritään kehittämään, parantamaan, jakamaan ja arvioimaan työkaluja, käytäntöjä ja lähestymistapoja terveyteen liittyvillä alueilla. Niitä on ollut ja on tällä hetkellä käynnissä lukuisista eri terveysaiheista. EU-JAV on historiallisesti ainutlaatuinen panostus rokotustoiminnan kehittämisen eteen niin rahallisesti kuin siihen osallistuvien tahojen osalta.

Suomesta Sosiaali- ja terveysministeriö (STM) ja Terveyden ja hyvinvoinnin laitos (THL) ovat 
aktiivisesti mukana EU-JAV:in eri toiminnoissa. THL vastaa muun muassa hankkeen rokotusluottamusta ja -vastaisuutta käsittelevän osion johtamisesta, ja STM on edustettuna eri maiden edustajista koostuvassa Member State Committee -johtoryhmässä.

Vaikka julkisuudessa - ja tutkimusyhteisössäkin - usein korostetaan rokotusvastaisuuteen liittyviä haasteita, käsitellään EU-JAV-hankkeen puitteissa myös useita muita rokotuskattavuuteen vaikuttavia asioita, kuten rokotuskattavuuden seurantaa, rokotteiden kysyntää ja tarjontaa ja tutkimuskysymysten priorisointia. Tämä monipuolinen lähestymistapa on tärkeää, mikäli rokotuskattavuutta halutaan aidosti vahvistaa.

Rokotusrekisterit mahdollistavat rokotuskattavuuden tarkastelun ja seurannan, ja erilaisia rokotusrekistereitä on käytössä useimmissa Euroopan maissa. Täsmällisimmin rokotusrekisterit toimivat, kun ne on yhdistetty mahdollisimman saumattomasti kansallisiin potilastietojärjestelmiin, kuten esimerkiksi Suomessa. Useissa maissa on kuitenkin vielä käytössä paljon epävarmempiin tiedonkeruutapoihin perustuvia rokotusrekistereitä. EU-JAV:issa arvioidaan rokotusrekistereiden yhteensopivuutta Euroopassa, pilotoidaan yhteisiä tapoja tehdä rokotuskattavuusarviointeja sekä selvitetään mahdollisuuksia kehittää yhteiseurooppalainen muistutusjärjestelmä, jotta rokotukset eivät jäisi ottamatta unohduksen vuoksi.

Myös EU-JAV:issa käsitellään rokotteiden kysyntään ja tarjontaan liittyviä asioita. Hankkeen puitteissa kehitetään muun muassa yhteisiä periaatteita rokotteiden kysynnän ja tarjonnan määrittelylle ja ennustamiselle sekä selvitetään edellytyksiä näihin liittyvien tietojen jakamiselle Euroopassa.

Vaikka EU-JAV ei ole varsinainen tutkimushanke, eli sen ensisijainen tehtävä ei ole tuottaa tutkimustietoa rokotteista tai rokottamisesta, käsitellään sen puitteissa kuitenkin myös tutkimukseen liittyviä asioita. Toistaiseksi työ on keskittynyt määrittelemään tuhkarokko-, hinkuyskä-, influenssa- ja HPV-rokottamisen tärkeimmät tietokuilut, joista on tarkoitus järjestää hankekilpailuja yhdessä komission tutkimuksesta vastaavan direktoraatin kanssa.

Vähemmän huomiota herättävien aiheiden lisäksi myös rokotusluottamukseen, -epäröintiin ja rokotteiden ottamiseen liittyvät asiat ovat vahvasti läsnä EU-JAV:issa. Niitä käsitellään lähes jokaisen erillisen toiminnon ja työpaketin yhteydessä sekä niitä varten tarkoitetussa erillisessä työpaketissa. Työpakettia johtaa THL yhdessä Italian kansanterveyslaitoksen ISS:n kanssa. Työpaketti "Vaccine hesitancy and uptake - from research and practices to implementation", koostuu kolmesta eri osiosta. Siinä kartoitetaan, mitä syitä korkean tai matalan rokotuskattavuuden taustalla on havaittu sekä mitä onnistuneiksi osoittautuneita keinoja ylläpitää hyvää rokotuskattavuutta ja -luottamusta on käytössä; miten ne toimivat, miten niitä on jalkautettu kansanterveystyöhön ja mitä on opittu näiden käytäntöjen toteuttamisesta, toimivuudesta ja arvioinnista. Tavoitteena on tunnistaa sellaista tutkimustietoa sekä sellaisia hyviä käytäntöjä, joiden jakaminen voi hyödyttää EU-maita niiden kansallisten rokotusohjelmien kehittämisessä. Työssä on vahvasti mukana ajatus siitä, ettei rokotusvastaisuus tai -epäröinti ole ainoa seikka, joka voi vaikuttaa rokotteiden ottamiseen - myös esimerkiksi palveluiden laatu ja vaivattomuus vaikuttavat paljon siihen, miten hyvin ihmiset ottavat rokotteita.

Tutkimustiedon ja hyvien käytäntöjen jakamista varten käytetään olemassa olevaa EU Health Policy Platform -portaalia. Sivustolla jaettava tieto on ensisijaisesti tarkoitettu eri maiden rokotusohjelmista vastaaville toimijoille, mutta myös muille rokotuskattavuuden parissa työskenteleville tahoille, kuten järjestöille ja tutkimuslaitoksille. Myös muut kuin EU-JAV:iin osallistuvat tahot voivat käyttää portaalia tiedon ja hyvien käytäntöjen jakamiseen.

EU-JAV:in puitteissa kehitetään myös työkalua sosiaalisen median seurantaa varten. Seuraamalla sosiaalista mediaa on mahdollista tunnistaa signaaleja, keskusteluja ja trendejä, joilla voi olla vaikutusta rokotusluottamukseen ja -kattavuuteen niin paikallisesti kuin laajemminkin.

\section{YHTEISTYÖTÄ TARVITAAN}

Periaatteessa kaikki käytännön rokottamiseen liittyvä työ tehdään kansallisella tasolla. Se, miten rokotusohjelmat toimivat eri maissa vaihtelee kuitenkin paljon; joissakin maissa, kuten Suomessa, kansallisen rokotusohjelman ohjaamisesta ja kehittämisestä vastaa kansanterveyslaitos (THL), kun taas joissakin maissa, kuten Italiassa ja Espanjassa, rokotusohjelmat toimivat pitkälti alueellisten viranomaisten alaisuudessa. 
Yllä kuvatut toimenpiteet yhteistyön lisäämiseksi sekä yhteisten voimavarojen hyödyntämiseksi ovat keskiössä, kun kansallista suorituskykyä kohdata rokottamiseen liittyviä haasteita pyritään vahvistamaan. Harvat käytännöt ja toimenpiteet ovat kuitenkaan suoraan siirrettävissä yhdestä maasta toiseen. Siksi, ja erityisesti nyt kun koronaepidemia on nopeasti vähentänyt tavanomaisia terveydenhuollon käyntejä, ja rokotetta SARS-CoV-2-virusta vastaan ollaan kehittämässä, kaikki tämä työ rokotuskattavuuden ja -luottamuksen sekä yhteistyön vahvistamiseksi on entistä tärkeämpää.

rokotuskattavuuteen vaikuttavat tekijät. Suomen lääkärilehti 10, VSK 73, 648-652.

\section{JonAS Sivelä}

FT, erikoistutkija

Infektiotautien torjunta ja rokotukset -yksikkö, Terveyden ja hyvinvoinnin laitos

\section{SARI EKHOLM \\ LKT, ylilääkäri \\ Turvallisuus- ja terveysosasto, Sosiaali- ja terveysministeriö}

TANELI PUUMALAINEN

LT, ylilääkäri

Infektiotautien torjunta ja rokotukset -yksikkö, Terveyden ja hyvinvoinnin laitos

\author{
Hanna Nohynek \\ LT, ylilä̈käri \\ Infektiotautien torjunta ja rokotukset -yksikkö, \\ Terveyden ja hyvinvoinnin laitos
}

